\title{
Paratenic hosts of the swimbladder nematode Anguillicola crassus
}

\author{
K. Thomas, F. Ollevier \\ Zoological Institute, Laboratory for Ecology and Aquaculture, Catholic University of Leuven, Naamsestraat 59, B-3000 Leuven, \\ Belgium
}

\begin{abstract}
The host specificity and population dynamics of Anguillicola crassus in a number of paratenic hosts were investigated. Various freshwater fish species were sampled monthly (March 1990 to March 1991) from the Kolenhaven (Albertcanal, Genk, Belgium) and examined for $L_{3}$-larvae of Anguillicola crassus. Sixteen species were found to be infected: all the physoclist species examined (Gymnocephalus cernua, Lepomis gibbosus, Ictalurus nebulosus, Stizostedion lucioperca, Gasterosteus aculeatus, Oreochromis niloticus and Perca fluviatilis) and those physostome species of which a sufficient number could be examined to detect the infection (Gobio gobio, Leuciscus cephalus, Chondrostoma nasus, Leuciscus leuciscus, Alburnus alburnus, Leuciscus idus, Scardinius erytrophthalmus, Rutilus rutilus and Tinca tinca). There were large differences in prevalence among the fish species examined but generally the prevalence was higher in physoclist fishes and was highest in $G$. cernua $(96 \%)$. In 4 species there was a significant positive correlation between fish length and parasite abundance. The percentage of grown larvae varied among fish species, being lowest in $G$. cernua and highest in $P$. fluviatilis. No clear seasonal incidence cycle was observed.
\end{abstract}

\section{INTRODUCTION}

Anguillicola crassus is a parasitic nematode of eels (Anguilla spp.) originating from South East Asia (Kuwahara et al. 1974). It was introduced to Europe a few years ago and spread quickly through most European countries (Peters \& Hartmann 1986, CanestriTrotti 1987, Dekker \& van Willigen 1987, Taraschewski et al. 1987, Dupont \& Petters 1988, Hellström et al. 1988, Køie 1988, Belpaire et al. 1989, Kennedy \& Fitch 1990, Székely et al. 1991).

The life cycle of Anguillicola crassus in the European eel Anguilla anguilla L. has been studied by De Charleroy et al. (1990). The adult nematode lives in the swimbladder lumen. The eggs, which contain $\mathrm{L}_{2}$-larvae at oviposition or hatched $\mathrm{L}_{2}$-larvae, reach the water after passage through the pneumatic duct and the intestine. When $\mathrm{L}_{2}$-larvae are ingested by freshwater cyclopoid copepods they develop in the haemocoel to the third infective stage $\left(\mathrm{L}_{3}\right)$ (De Charleroy et al. 1990). These larvae are infective to eels; however, since copepods are not considered a major food item for eels and because eels larger than $50 \mathrm{~cm}$ feed almost exclusively on fish (Tesch 1977, de Nie 1988) it was reasonable to assume that other fish species might act as a paratenic host (= reservoir host) for Anguillicola cras- sus. The Asian literature on the life cycle of Anguillicola spp. made no mention of the occurrence of paratenic hosts (Hirose et al. 1976, Wang \& Zhao 1980, Huang 1981, Kim et al. 1989). In Europe there are some reports on the occurrence of Anguillicola crassus larvae in various fish species other than eels (De Charleroy et al. 1990, Haenen \& van Banning 1990) and the possibility of the transfer of $\mathrm{L}_{3}$-larvae from experimentally infected ide and carp to eel was proven by De Charleroy et al. (1990) and for $\mathrm{L}_{3}$-larvae from smelt and ruffe by Haenen \& van Banning (1991).

The aim of this study was to determine the host specificity of Anguillicola crassus for the paratenic host. Fish were examined every 2 wk to exclude the possibility that they might be infected for restricted seasons and to investigate if any seasonality of infection occurred. The infection of eels with $A$. crassus at the same location was studied simultaneously, but the data will be published elsewhere.

\section{MATERIAL AND METHODS}

During a 13 mo period (March 1990 to March 1991) a range of freshwater fish species were sampled every 2 wk at the Kolenhaven (Coal Harbour), a deadend side- 
arm of the Albertcanal, close to Genk, Belgium $\left(51^{\circ} \mathrm{N}\right.$, $\left.5^{\circ} 5^{\prime} \mathrm{E}\right)$. The Albertcanal connects the rivers Scheldt and Meuse over a distance of $108 \mathrm{~km}$. The Kolenhaven itself is $900 \mathrm{~m}$ long and $80 \mathrm{~m}$ wide with a mean depth of $3.5 \mathrm{~m}$. The water temperature reached a maximum in August $\left(24.5^{\circ} \mathrm{C}\right)$ and a minimum in February $\left(7.0^{\circ} \mathrm{C}\right)$ The water contains a rich phytoplankton community Zooplankton consists of 3 major groups: Rotatoria, Copepoda and Cladocera. The fact that 39 fish species have been sampled so far indicates a reasonably rich community. The most abundant species are roach, bleak, eel and ruffe; the highest biomasses per ha are recorded for eel and roach. The eel population consists mainly of large size classes (Verreycken et al. 1990).

The adjacent powerplant draws a considerable volume of cooling water $\left(50000 \mathrm{~m}^{3} \mathrm{~h}^{-1}\right)$ from the Albertcanal. The water is pumped through the condensor and cooling tower but passes first through screens to sort out fish and debris. Most fish examined in this study were sampled from these screens (fish might be alive or dead); larger-sized fish were also caught with fykes placed in the Kolenhaven. As the species diversity and total number of fish on the screens changed with time, we were unable to examine samples of each fish species every month. The fish were measured, weighed and dissected at the laboratory. Live fish and partially decomposed fish collected from the screens were examined immediately; others were frozen and examined later on (in fish preserved in $70 \%$ ethanol, Anguillicola crassus larvae became completely transparent, making them extremely difficult to find; thus this method is not recommended). The swimbladders, including the surrounding mesenteric tissues, were pressed between glass plates and examined for the presence of A. crassus larvae under a stereomicroscope with transmitted light. Because some fish were frozen it was impossible to estimate the viability of all larvae. Length and width of 85 larvae (fixed in $4 \%$ formalin) from 7 fish species were measured using Videoplan (Image Analysis System Kontron Bildanalyse) and scanning electron microscopy (SEM) was carried out on the $\mathrm{L}_{3}$-larvae from Gymnocephalus cernua and from experimentally infected carp. To be sure of their capability of transmission we force-fed an uninfected eel with a swimbladder of $G$. cernua containing 50 larvae.

Statistical analysis of the data of relevant fish species included logistic regression analysis [with maximum likelihood estimates (SAS Institute Inc. 1989)] of prevalence and abundance upon the variables length and time, Fisher's exact test, Kruskal-Wallis test and Spearman (and Pearson) rank correlation coefficient. The variance to mean ratio $\left(s^{2} / \bar{x}\right)$ of parasite abundance was calculated to provide an index of the degree of overdispersion of Anguillicola sp. in different length classes and different months. The $Z$-test for unmatched samples was used to compare the infection in Gymnocephalus cernua caught by fykes with those on the screens. A host-specificity index based on intensities of infection was calculated using the formula proposed by Rohde (1980).

The terms 'prevalence', 'mean intensity' and 'abundance' are used according to the recommendations of Margolis et al. (1982).

\section{RESULTS}

\section{Prevalence and abundance}

Altogether 2088 fishes from 24 species, belonging to 7 different families and 5 orders, were examined over a period of 13 mo. Except for 6 species which were rare and 2 species which had been restocked in wintertime in the Albertcanal (Leucaspius delineatus and Rhodeus sericeus amarus), all other (16) species were seen infected with $\mathrm{L}_{3}$-larvae at least once (Table 1). The highest prevalence $(95.7 \%)$ and mean intensity (20.6 $L_{3}$-larvae per infected fish) were found in Gymnocephalus cernua, followed by Lepomis gibbosus and Ictalurus nebulosus. Species belonging to the Perciformes, Siluriformes and Gasterosteiformes show a higher prevalence and mean intensity than most Cypriniformes, except for Chondrostoma nasus and 3 species of which we examined only 1 or 2 individuals (Leuciscus cephalus, Leuciscus leuciscus and especially Gobio gobio) which might be highly infected species also. Four species (Rutilus rutilus, Scardinius erythrophthalmus, Leuciscus idus and Alburnus alburnus) were only occasionally infected and then only with 1 to 4 larvae. Tinca tinca, Leucaspius delineatus and Rhodeus sericeus amarus were restocked in winter: 3 mo later just 1 tench was infected. Insufficient specimens were examined from the other species to detect a possible infection.

Overall mean intensity and range of $\mathrm{L}_{3}$-larvae differed among the fish species. Mean intensity was highest in those species which showed the highest prevalence (Gymnocephalus cernua, Lepomis gibbosus and Ictalurus nebulosus), and was significantly lower for all the other species. Host-specificity index based on intensity of infection amounted to 0.52 (where this index approaches 1 for parasites restricted to a single host species; Rohde 1980). This index only relates to the presence of larvae (intensity) and not to their viability or capability of transmission to eels.

To verify if fish which were drawn with the stream onto the screens were more heavily infected with Anguillicola crassus larvae than those fish caught by fykes, a comparison of the abundance in Gymnocephalus cernua the only species of which enough fish 
Table 1. Anguillicola crassus. Summary of all fish species examined, ranked according to the prevalence of parasite infection and separated into physoclist and physostome species. Parentheses indicate too few fish were examined or only 1 fish was infected

\begin{tabular}{|c|c|c|c|c|c|c|c|}
\hline Species & $\begin{array}{c}\text { No. } \\
\text { examined }\end{array}$ & $\begin{array}{l}\text { Mean } \\
\text { length } \\
(\mathrm{cm})\end{array}$ & $\begin{array}{c}\text { Prevalence } \\
(\%)\end{array}$ & $\begin{array}{c}\text { Mean } \\
\text { intensity }\end{array}$ & $\begin{array}{l}\text { Range } \\
\min -\max \end{array}$ & Abundance & $\begin{array}{l}\text { Variance/ } \\
\text { mean } \\
\text { abundance }\end{array}$ \\
\hline \multicolumn{8}{|l|}{ PHYSOCLIST } \\
\hline Gymnocephalus cernua (ruffe) ${ }^{1 . *}$ & 209 & 8.8 & 95.7 & 20.6 & $1-146$ & 19.7 & 15.2 \\
\hline Lepomis gibbosus (pumpkinseed) ${ }^{2 \cdot}$ & 20 & 13.7 & 80 & 168 & $2-44$ & 13.4 & 14.5 \\
\hline Ictalurus nebulosus (brown bullhead) ${ }^{3}$ & 20 & 17.3 & 75 & 12.3 & $1-34$ & 9.2 & 11.9 \\
\hline Stizostedion lucioperca (pike-perch) ${ }^{1 .}$ & 445 & 10.7 & 65.4 & 3.0 & $1-34$ & 1.9 & 4.9 \\
\hline Gasterosteus aculeatus (stickleback) ${ }^{4}$ & 60 & 4.3 & 46.7 & 2.9 & $1-9$ & 1.4 & 3.1 \\
\hline Oreochromis niloticus (tilapia) $)^{5,}$ & 68 & 3.9 & 32.4 & 1.6 & $1-4$ & 0.5 & 1.8 \\
\hline Perca fluviatilis (perch) & 378 & 11.4 & 26.2 & 3.0 & $1-18$ & 0.8 & 5.1 \\
\hline \multicolumn{8}{|l|}{ PHYSOSTOME } \\
\hline Gobio gobio (gudgeon) ${ }^{6}$ & 2 & 15.4 & $(100)$ & (11) & $10-12$ & (11) & - \\
\hline Leuciscus cephalus (chub) ${ }^{6}$ & 1 & 7.0 & $(100)$ & (3) & 3 & (3) & - \\
\hline Chondrostoma nasus (nose-carp) & 181 & 5.5 & 50.3 & 3.4 & $1-23$ & 1.7 & 5.2 \\
\hline Leuciscus leuciscus (dace) ${ }^{6}$ & 2 & 12.4 & $(50)$ & $(2)$ & 2 & $(2)$ & - \\
\hline Alburnus alburnus (bleak) ${ }^{6}$ & 252 & 12.7 & 15.5 & 1.4 & $1-4$ & 0.2 & 1.6 \\
\hline Leuciscus idus (ide) ${ }^{6}$ & 14 & 7.3 & 14.3 & (1) & 1 & $(0.07)$ & - \\
\hline Scardinius erythrophthalmus (rudd) ${ }^{6}$ & 109 & 7.6 & 2.7 & 2 & $1-4$ & 0.06 & - \\
\hline Rutilus rutilus (roach) ${ }^{6}$ & 106 & 11.5 & 1.9 & (1) & 1 & $(0.01)$ & - \\
\hline Tinca tinca $(\text { tench })^{6}$ & 68 & 6.5 & 1.5 & (1) & 1 & $(0.02)$ & - \\
\hline Leucaspius delineatus (rain bleak) ${ }^{6}$ & 112 & 6.2 & 0 & - & - & - & - \\
\hline Cyprinus carpio (carp) ${ }^{6}$ & 10 & 12.3 & 0 & - & - & - & - \\
\hline Carassius auratus gibelio (gibel carp) ${ }^{6}$ & 1 & 7.6 & 0 & - & - & - & - \\
\hline Rhodeus sericeus amarus (bitterling) ${ }^{6}$ & 8 & 5.7 & 0 & - & - & - & - \\
\hline Barbus barbus (barbel) ${ }^{6}$ & 2 & 9.9 & 0 & - & - & - & - \\
\hline Abramis brama (bream) ${ }^{6}$ & 8 & 10.2 & 0 & - & - & - & - \\
\hline Salmo trutta fario (brown trout) ${ }^{7}$ & 11 & 16.7 & 0 & - & - & - & - \\
\hline Salmo salar (salmon) ${ }^{7}$ & 1 & 19.3 & 0 & - & - & - & - \\
\hline
\end{tabular}

were caught by fykes) was done using the Z-test for unmatched samples. With or without eliminating the results of the smaller fry, which were only found on the screens, there was no significant difference in abundance $(Z<<1.96)$. There is no indication that infection with $A$. crassus larvae influences the condition of the fish.

\section{Appearance and identification of Anguillicola crassus larvae}

All larvae found in or around the swimbladder in the different fish species were determined as $\mathrm{L}_{3}$-larvae of Anguillicola crassus. No pathological effects of the larvae upon the swimbladder were found.

SEM study of the $\mathrm{L}_{3}$-larvae from Gymnocephalus cernua revealed the morphological characteristics typical of $\mathrm{L}_{3}$-larvae isolated from experimentally infected carps. They include a rounded head end with 4 papillae, 2 amphids and 2 vertically orientated labia which surround a split-shaped mouth opening. Even with the stereomicroscope the typical pointed labia are visible
(Fig. 1). SEM pictures of the $\mathrm{L}_{3}$-larvae are given in Höglund \& Thomas (in press).

In the eel which was force-fed a whole swimbladder of ruffe containing 50 larvae, 23 larvae were recovered after 1 mo. Only 6 larvae had developed into the $\mathrm{L}_{4}$ larval stage.

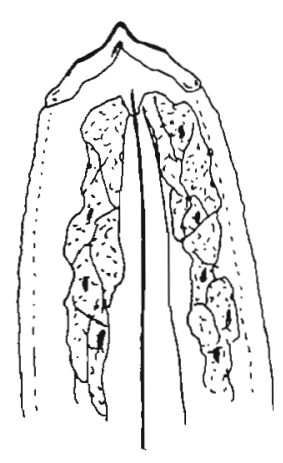

A. crassus

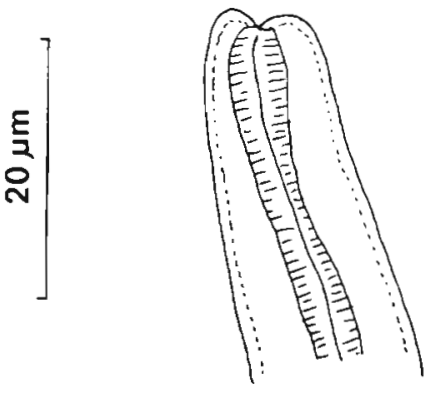

R. acus
Fig. 1. Anguillicola crassus, Raphidascaris acus. Anterior end of $\mathrm{L}_{3}$-larva of $A$. crassus and $\mathrm{L}_{2}$-larva of $R$. acus (after Smith 1984) 
Normally $\mathrm{L}_{3}$-larvae were not encapsulated and their viability could easily be detected by their movements. They survived for at least $24 \mathrm{~h}$ after the death of their fish host. However, encapsulated viable- and dead larvae were also found. Although we could not always determine the viability of the larvae it was clear that dead larvae and remnants occurred in various species.

Within species with a high prevalence and mean intensity (Gymnocephalus cernua and Lepomis gibbosus), encapsulated wormlike structures in different shapes and sizes were found which we could not positively identify as dead $\mathrm{L}_{3}$-larvae, but which we assumed to be degenerated larvae because of their high prevalence in heavily infected species. In $66 \%$ of the infected $G$. cernua these remnants were present; in 1 fish, 88 of them were counted. L. gibbosus is also characterized by the presence of remnants (in $56 \%$ of the infected fish) and a high number of dead larvae. Stizostedion lucioperca by contrast had more viable larvae and only occasionally (in $2 \%$ ) were remnants found. In Alburnus alburnus dead larvae and remnants were observed once. Nevertheless we did not take any possible degenerated larvae into account in our calculations of intensity.

No significant differences in body length, body width and oesophagus length of most $\mathrm{L}_{3}$-larvae found in the various fish species were detected (Table 2 ). The ratio of body length to oesophagus length together with the ratio of length to width could probably be used for determining the larvae and distinguishing them from other nematode larvae. Nevertheless, body length and oesophagus length of these $\mathrm{L}_{3}$-larvae were larger than indicated by Haenen \& van Banning (1990) which makes determination based upon measurements less plausible. In some fish species (most physoclists) $\mathrm{L}_{3}$ larvae can develop further: they become bigger in size and the intestine becomes darker with or without reaching the $\mathrm{L}_{4}$-stage (less mobile, dark-coloured intestine). Such further-developed larvae are more embedded in the swimbladder wall and are easily damaged when trying to remove them. Therefore only 1 grown larva was measured to provide an indication of length and width on which they rest (Table 2) all larvae of that size or bigger are called 'further-developed' or 'grown' larvae in contrast with the small infective mobile $\mathrm{L}_{3}$-larvae. These grown larvae were detected in Perca fluviatilis, Gasterosteus aculeatus, Stizostedion lucioperca, Lepomis gibbosus, Gobio gobio, Gymnocephalus cernua and Oreochromis niloticus (Fig, 2). In Gymnocephalus cernua only $0.2 \%$ of more than 4000 larvae were grown. In S. lucioperca, L. gibbosus and $O$. niloticus the percentage of further-developed larvae was also very small. However, in $P$. fluviatilis more than $40 \%$ of 295 larvae were further developed, and until now we have no indication that grown larvae are still infective to eel. Perch was the only species in which we could find $\mathrm{L}_{4}$-larvae and pre-adult worms (pre-adults formed $7 \%$ of all Anguillicola crassus found in perch) alive in the swimbladder wall or even in the lumen. They reach the same length as pre-adults in eel. Up to 5 pre-adult worms were found in 1 perch (length $17 \mathrm{~cm}$.

Some of the fish species examined in this study are intermediate hosts for Raphidascaris acus larvae which generally stay in the wall of the digestive tract and liver (Smith 1984). No $R$. acus larvae were found in this study due to the fact that only swimbladder tissue and mesenteric tissues were examined. The chance that there is any confusion between $\mathrm{L}_{2}$-larvae of $R$. acus and $L_{3}$-larvae of Anguillicola crassus is limited due to their different predilection sites and can be avoided by comparing the ratio between body length and oesophagus

Table 2. Anguillicola crassus. Comparison of morphometric characteristics of $\mathrm{L}_{3}$-larvae in various freshwater fish species from the Kolenhaven with (") larvae from experimentally infected carp and with (") data from Haenen \& van Banning (1990). Measurements expressed in $\mathrm{mm}$

\begin{tabular}{|c|c|c|c|c|c|c|}
\hline Species & $\begin{array}{l}\text { No. of } \\
\text { larvae } \\
\text { measured }\end{array}$ & $\begin{array}{c}\text { Mean body } \\
\text { length } \\
L\end{array}$ & $\begin{array}{c}\text { Mean } \\
\text { oesophagus } \\
\text { length } \\
0\end{array}$ & $\begin{array}{c}\text { Mean body } \\
\text { width } \\
W\end{array}$ & $2 / O$ & $L W$ \\
\hline Gymnocephalus cernua & 31 & 0.90 & 0.26 & 0.034 & 3.5 & 26.6 \\
\hline Chondrostoma nasus & 13 & 0.91 & 0.26 & 0.034 & 3.6 & 26.9 \\
\hline Scardinius erytrophthalmus & 3 & 0.94 & 0.27 & 0.037 & 3.4 & 25.2 \\
\hline Stizostedion lucioperca & 20 & 0.89 & 0.27 & 0.035 & 3.3 & 26.0 \\
\hline Oreochromis niloticus & 6 & 0.89 & 0.27 & 0.035 & 3.3 & 26.0 \\
\hline Alburnus alburnus & 5 & 0.87 & 0.27 & 0.041 & 3.6 & 23.2 \\
\hline Lepomis gibbosus & 6 & 0.95 & 0.27 & 0.049 & 3.7 & 20.4 \\
\hline Cyprinus carpio $\left({ }^{\circ}\right)$ & 33 & 0.92 & - & 0.037 & - & 24.9 \\
\hline Various species $(\cdots)$ & 15 & 0.68 & 0.21 & - & 3.2 & - \\
\hline Stizostedion lucioperca grown larva & 1 & 1.22 & 0.34 & 0.076 & 3.6 & 16.1 \\
\hline
\end{tabular}


Fig. 2. Anguillicola crassus. Percentage of grown larvae (big $\mathrm{L}_{3}, \mathrm{~L}_{4}$ or pre-adult worms). Total no. of larvae found in various fish species is given to right of bar

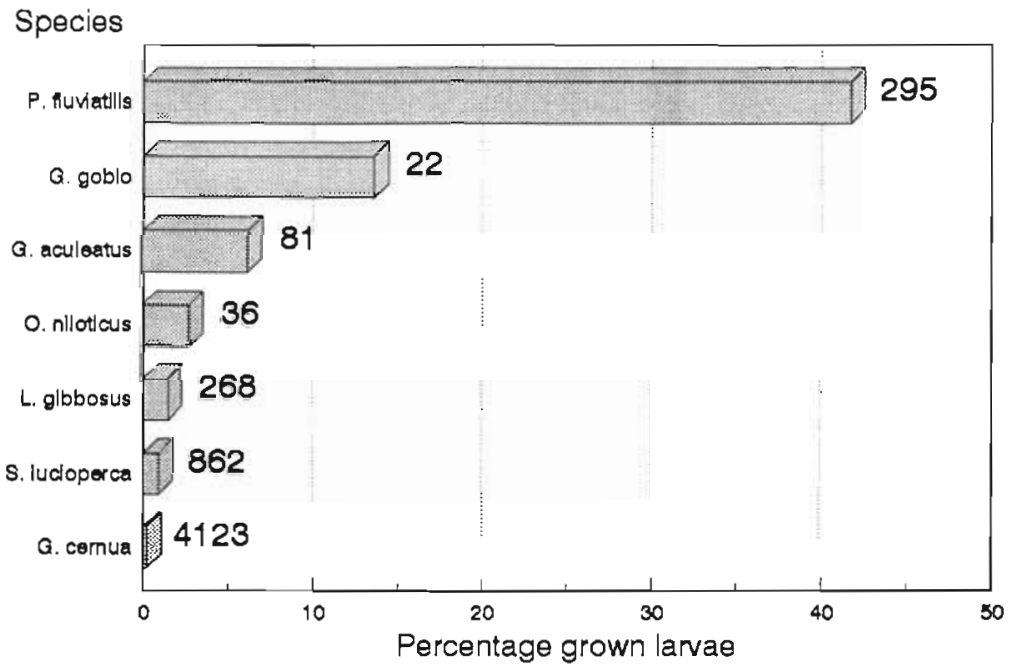

length (mean $L / O=5.8$ in $R$. acus and mean $L / O=3.5$ in $A$. crassus) and the morphology of the head end, which is only pointed in $A$. crassus (Fig. 1).

\section{Fish length and parasite infection}

Mean length of the various fish species examined was different (Table 1): from 3.9 up to $19.3 \mathrm{~cm}$. A striking feature is that the minimum and maximum length in which $\mathrm{L}_{3}$-larvae were found was nearly equal to the range of lengths examined (Fig. 3). The largest infected fish were Stizostedion lucioperca $(25 \mathrm{~cm}$ with 6 larvae, $31.5 \mathrm{~cm}, 1$ larva) and Perca fluviatilis (31 cm and $33.5 \mathrm{~cm}$, each with 1 larva). The smallest fish infected were Gasterosteus aculeatus $(2.4 \mathrm{~cm}, 1$ larva), Oreochromis niloticus (2.7 cm, 1 larva) and Gymnocephalus cernua $(2.7 \mathrm{~cm}$ with 1 larva and $2.9 \mathrm{~cm}$ with 15 larvae!).

Prevalence increased with length in Chondrostoma nasus and Oreochromis niloticus, 2 species which were only caught as fry in summer. In Perca fluviatilis a significant quadratic relationship between prevalence (p) and length $(L)$ was found: $\operatorname{logit}(p)=-0.9+0.7 L$ $-0.03 L^{2} ; \mathrm{p}<0.01$. Fry and large $(>20 \mathrm{~cm})$ fish were less infected than fish between 10 and $20 \mathrm{~cm}$. However, it is necessary to take into account that this quadratic equation form is due to a small number of large fish. In the other species no significant correlation between length and prevalence was observed.

There was a significant positive (Spearman rank) correlation between fish length and abundance in 4 species only: Perca fluviatilis $(\mathrm{r}=0.47, \mathrm{p}<0.0001)$; Gymnocephalus cernua $(\mathrm{r}=0.23, \mathrm{p}<0.001)$; Chondrostoma nasus $(\mathrm{r}=0.33, \mathrm{p}<0.0001)$; and Oreochromis niloticus $(\mathrm{r}=0.32, \mathrm{p}<0.009)$ and the Pearson correlation was also only significant in these 4 species. $P$. fluviatilis showed also a quadratic equation form between length $(L)$ and abundance $(a)$ : $\operatorname{logit}(a)=-7.6$
Fig. 3. Range of fish length examined and range wherein infection was detected. (*): length with the highest no. of Anguillicola crassus larvae for each fish species. Occasionally infected fish species not shown

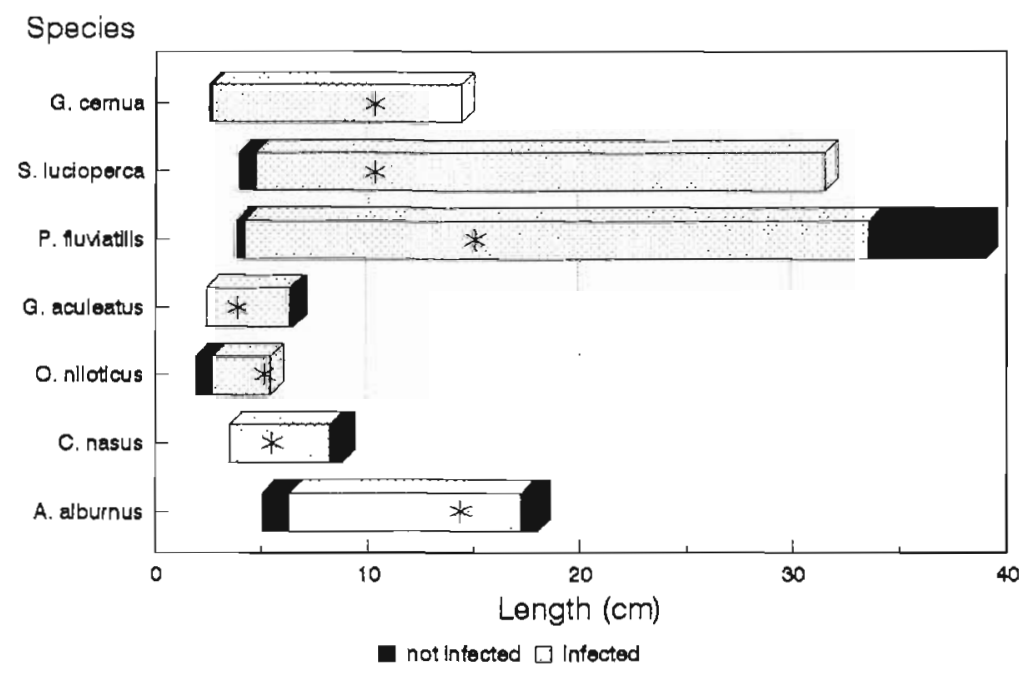


$+0.4 L-0.02 L^{2} ; \mathrm{p}<0.01$. Prevalence and abundance for different size classes increased with increasing length for these 4 species but did not for Gasterosteus aculeatus $(\mathrm{p}=0.5)$ or Stizostedion lucioperca $(p=0.2)$ (Table 3). Variance to mean ratio calculated for the different size classes indicated an overdispersed distribution except for the smallest size class of $O$. niloticus. In Table 1 variance to mean ratio is calculated for each species without regard of size classes, which must be considered critically because distribution will be aggregated over all age classes (Anderson 1987), but even within each size class overdispersion was detected (Table 3 ). In some species this ratio showed first a rise and then a decline in larger fish, but in the small-sized $O$. niloticus and Gasterosteus aculeatus and in Gymnocephalus cernua only a rise was noted. In $O$. niloticus and Gasterosteus aculeatus the maximum number of larvae was considerably less than in most species where larger size classes were also examined (Fig. 1). The length in which the maximum number of larvae was found is shown in Fig. 3. Neither the very small fish nor the largest carry the highest number of larvae.

The occurrence of grown larvae in Perca fluviatilis also showed a positive correlation with fish length $(r=0.33, p<0.0001)$ and there was a significant positive correlation between total number of larvae and grown larvae $(r=0.72, p<0.0001)$. Pre-adult worms were only found in perch between 9.3 and $31 \mathrm{~cm}$.

The occurrence of degenerated larvae in Gymnocephalus cernua was spread over all lengths but was less frequent in fry.

\section{Seasonal dynamics}

June, July and August were characterized by the appearance of a new generation of fish: especially fry from Perca fluviatilis, Stizostedion lucioperca, Chondrostoma nasus, Gymnocephalus cernua and Oreochromis niloticus. Prevalence and abundance increased significantly during the summer months in growing fingerlings of $O$. niloticus, $C$. nasus and $G$. cernua. The same trend could be perceived in the other 2 species. However, $P$. fluviatilis fingerlings were considerably less infected in comparison with the other fingerlings (Table 3).

Monthly data on the occurrence of Anguillicola crassus are available for Perca fluviatilis, Stizostedion lucioperca and Gymnocephalus cernua (Fig. 4). Prevalence of infection stayed nearly the same throughout the year in G. cernua $(100 \%)$ with the lowest value in spring; in $S$. lucioperca prevalence rose steadily during the summer and reached a peak in October $(87.2 \%$ ) and in $P$. fluviatilis it fluctuated between $5.6 \%$ in May and $76.9 \%$ in October. No clear or similar trends were apparent in mean intensity or variance to mean ratio; this fluctuated erratically for G. cernua (between 3.0 in May and 37.7 in June).

In the logistic regression analysis of prevalence and abundance, data (of 6 species) were combined by seasons or warm/cold periods of the year. There were no significant relationships valid for all species, but length or length in combination with time seemed to be more important than time of the year. Infections appeared to be lower in springtime, but spring was only signifi-

Table 3. Anguillicola crassus. Prevalence, abundance and variance to mean abundance ratio $\left(s^{2} / \bar{X}\right)$ of parasite in various size classes of fish. Only the first 4 species showed a significant positive correlation between fish length and parasite abundance

\begin{tabular}{|c|c|c|c|c|}
\hline Species & $\begin{array}{l}\text { Size class } \\
(\mathrm{cm})\end{array}$ & $\begin{array}{c}\text { Prevalence } \\
(\%)\end{array}$ & Abundance & $s^{1 / \bar{X}}$ \\
\hline Oreochromatis niloticus & $\begin{array}{l}1.9-4.0 \\
4.1-5.4\end{array}$ & $\begin{array}{l}26.8 \\
40.7\end{array}$ & $\begin{array}{l}0.32 \\
0.85\end{array}$ & $\begin{array}{l}1.0 \\
1.9\end{array}$ \\
\hline Chondrostoma nasus & $\begin{array}{l}3.5-4.9 \\
5.0-6.9 \\
7.0-8.8\end{array}$ & $\begin{array}{l}36.4 \\
54.5 \\
81.3\end{array}$ & $\begin{array}{l}0.9 \\
1.9 \\
3.9\end{array}$ & $\begin{array}{l}3.1 \\
5.7 \\
3.6\end{array}$ \\
\hline Gymnocephalus cernua & $\begin{array}{c}2.1-6.9 \\
7.0-10.0 \\
10.1-15.0\end{array}$ & $\begin{array}{r}100.0 \\
93.8 \\
98.2\end{array}$ & $\begin{array}{l}10.7 \\
18.9 \\
26.2\end{array}$ & $\begin{array}{r}11.0 \\
9.7 \\
22.6\end{array}$ \\
\hline Perca fluviatilis & $\begin{array}{r}3.1-10.0 \\
10.1-20.0 \\
20.1-39.0\end{array}$ & $\begin{array}{r}6.1 \\
40.1 \\
57.1\end{array}$ & $\begin{array}{l}0.1 \\
1.2 \\
2.0\end{array}$ & $\begin{array}{l}2.2 \\
5.0 \\
3.9\end{array}$ \\
\hline Gasterosteus aculeatus & $\begin{array}{l}2.4-4.0 \\
4.1-7.0\end{array}$ & $\begin{array}{l}68.0 \\
31.4\end{array}$ & $\begin{array}{l}1.5 \\
1.3\end{array}$ & $\begin{array}{l}1.9 \\
4.4\end{array}$ \\
\hline Stizostedion lucioperca & $\begin{array}{r}3.1-10.0 \\
10.1-20.0 \\
21.1-31.5\end{array}$ & $\begin{array}{l}60.8 \\
68.8 \\
63.6\end{array}$ & $\begin{array}{l}1.5 \\
2.3 \\
1.7\end{array}$ & $\begin{array}{l}2.2 \\
6.0 \\
2.8\end{array}$ \\
\hline
\end{tabular}



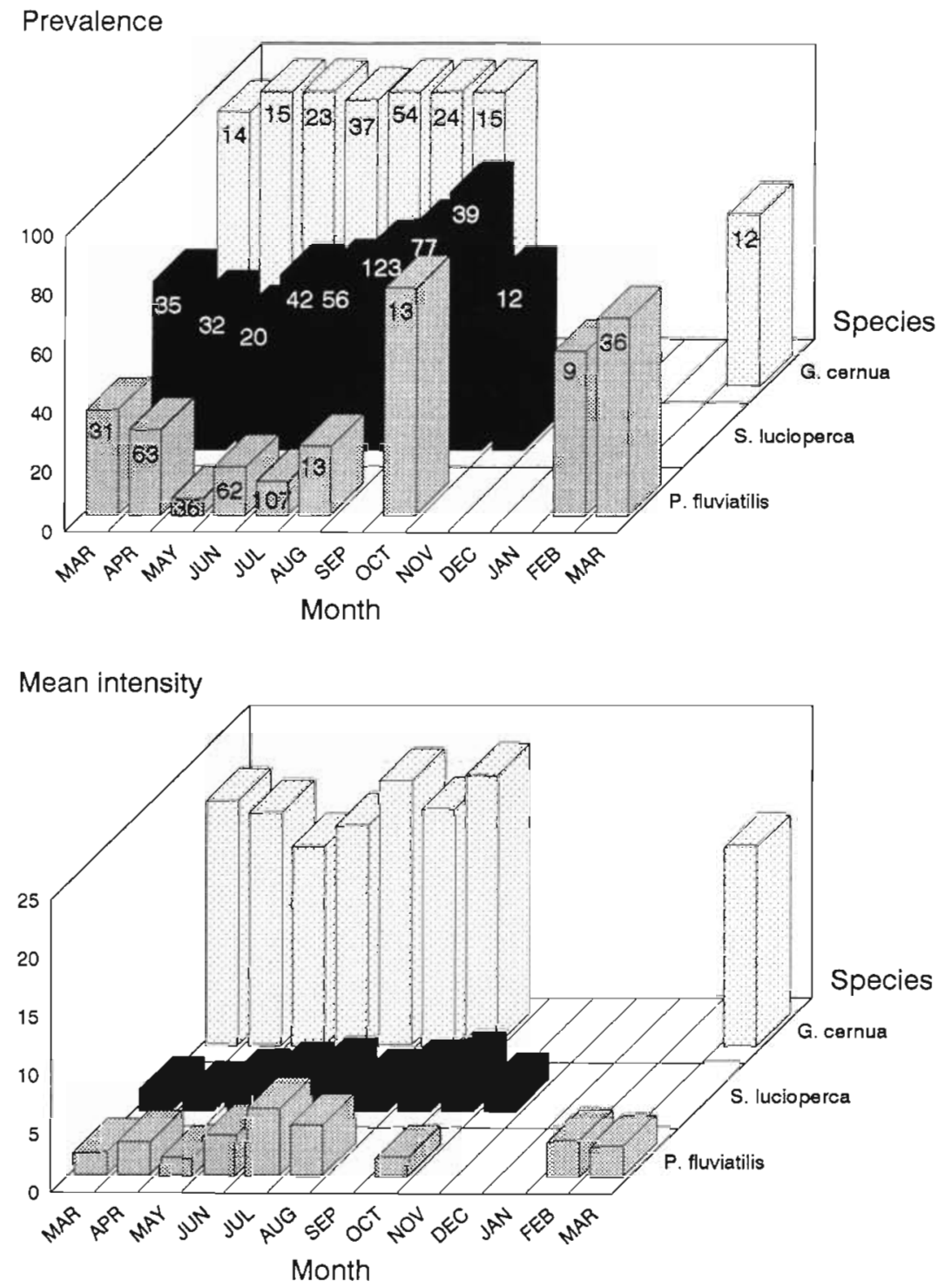

Fig. 4. Anguillicola crassus. Monthly changes in prevalence, mean intensity and variance to mean ratio of parasite in Gymnocephalus cernua, Stizostedion lucioperca and Perca fluviatilis (only those months are shown where more than 8 fish were examined)

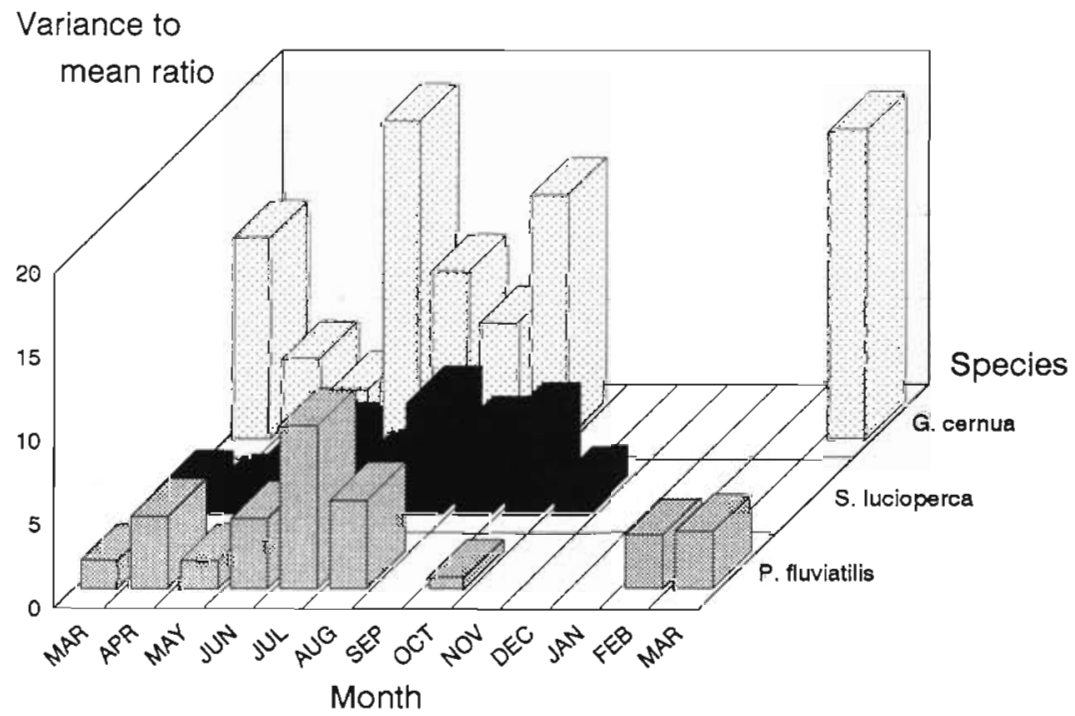




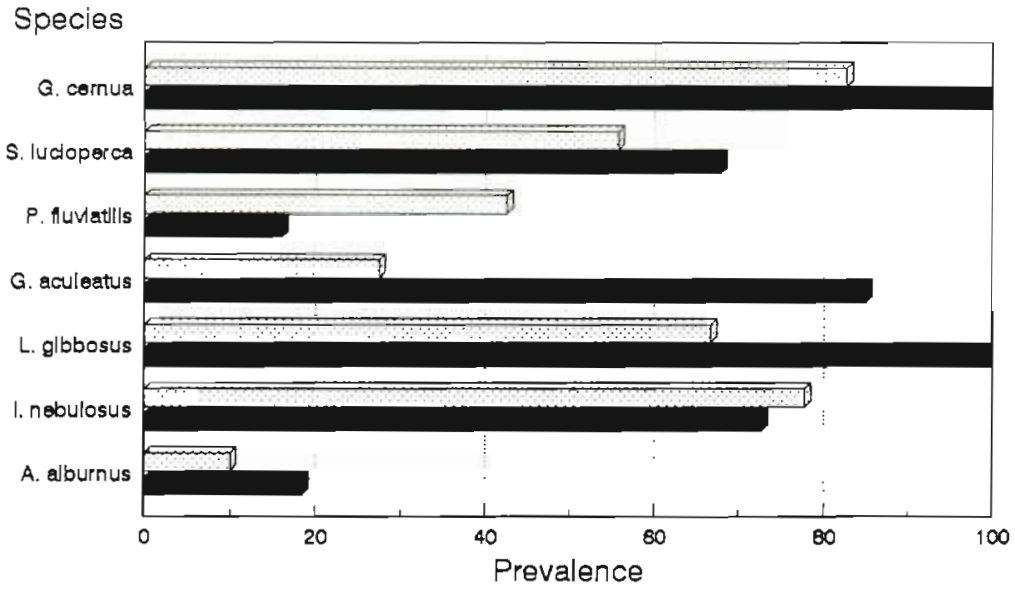

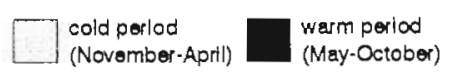

Fig. 5. Anguillicola crassus. Prevalence of parasite in various fish species in the warm (May to October) and cold period (November to April) of the year cantly different from other seasons in Stizostedion lucioperca. In Perca fluviatilis, S. Iucioperca and Gymnocephalus cernua abundance was significantiy positively influenced in the warm period (May to October). Prevalence was always higher in the warm period except for $P$. fluviatilis and Ictalurus nebulosus, but was only significant higher in G. cernua, S. Iucioperca and Gasterosteus aculeatus (Fig. 5). Abundance was always higher in the warm period, except for $P$. fluviatilis, but it was only significantly higher in $S$. lucioperca and Alburnus alburnus. There are thus indications for some species, at least, that infections occur primarily during summer when prevalence and abundance increase and that over winter, infections are lower.

\section{DISCUSSION}

The present study shows that a great variety of freshwater fish species can carry Anguillicola crassus larvae. This part of the life cycle has not been noticed in Asia, the original region of the nematode, and has been studied in Europe only within the last 3 years. In comparison to the study of Haenen \& van Banning (1990) more species were infected and the range in numbers of larvae found in the various species was broader.

Considering only the more frequently infected species, infection was not restricted to a certain size class. Young fry (length ca $3 \mathrm{~cm}$ ) captured on the screens were already infected with Anguillicola crassus larvae and during the summer abundance increased in these growing fingerlings. In older fish a positive correlation was found between fish length and abundance only in ruffe and perch; for perch this trend stopped above $30 \mathrm{~cm}$. In all species and size classes an overdispersed distribution was found, except in the smallest size class of Oreochromis niloticus. A random distribution of parasites in the early stages of host colonization is often observed (Anderson 1978). One of the reasons for overdispersion in older fish might be the individual variability in prey selection.

There were no clear seasonal patterns among the parasite populations in 3 fish species (Perca fluviatilis, Stizostedion lucioperca, Gymnocephalus cernua): erratic fluctuations in prevalence and abundance were found. However, infection appeared to be lower in spring and higher in the warm period (May to October) (significant for only 2 species) : indicating that transmission occurs primarily during summer.

Larval survival rate in the various fish species is not known and data are contradictory. The fact that no clear seasonal patterns in abundance were found favours the hypothesis of a high longevity of the larvae. But as $0+$ ruffe already contained some degenerated larvae at the end of June, a survival of just a few months is assumed. The high prevalence of degenerated larvae in ruffe and pumpkinseed, 2 heavily infected species, could also indicate a short survival. On the other hand, pike-perch of all size classes mostly showed live larvae, so longevity of Anguillicola crassus larvae might differ from fish species to species.

The appearance of Anguillicola crassus larvae in physoclist (closed swimbladder) and physostome (open swimbladder) fish species is different: first, the $\mathrm{L}_{3}$ larvae were found embedded in the swimbladder wall in physoclists but remained mainly loosely in the peritoneal covering surrounding the swimbladder in physostome fish species. Secondly, the prevalence of infection and mean intensity was generally lower in physostomes (Table 1). Thirdly, grown $\mathrm{L}_{3}$-larvae were not observed in physostome species (except once in Gobio gobio). Physoclist species examined in this study belonged to 5 different families and 3 orders, but all can be classified as Acanthopterygii. It is not clear if the difference in swimbladder structure or another physiological or ecological difference plays a role in these findings. 
Fish species examined in this study also exhibit different feeding ecology, although most fish feed on plankton during at least some period of their lives (Lazzaro 1987). Some of the most heavily infected species (ruffe, brown bullhead and gudgeon) are benthic fishes. This is in accordance with results from a study in Sweden (Höglund \& Thomas 1992; this issue) where Anguillicola crassus infection mainly occurred in fish species which are largely benthic (black goby, ruffe). A common characteristic of the highest infected Cypriniformes is the ventroterminal position of the mouth (in gudgeon, nosecarp, dace and chub). Others, such as bleak, ide, rudd and roach, which have a dorsoterminal or terminal mouth position, were rather occasionally infected. As the mouth position is one of the characteristics used to determine the feeding ecology of a fish (Keast \& Webb 1966), bottom feeding seems to provide more possibilities for infection. Within the physoclist species, the rather low prevalence in perch was due to the high proportion of smaller perches examined which were considerably less infected. Perch fingerlings eat small plankton but often form schools which stay in the upper layers of the water column. Young pike-perch and ruffe live in deeper water layers and showed a higher prevalence then perch. These data indicate that a benthic mode of life (in the deeper water layers) increases the chances of fish becoming infected with $A$. crassus larvae. Freeliving $L_{2}$-larvae sink to the bottom and in experimental conditions (probably also in nature) prevalence of infection in the intermediate host (copepods and ostracods) was highest near the bottom (authors' unpubl. data). Due to their bottom-dwelling mode of life and the restricting effect of mouth size, eels prefer rather small fish inhabiting the lake bottom surface (Sinha \& Jones 1967, de Nie 1988). A benthic mode of life enhances probability of infection and probability of transferring the $\mathrm{L}_{3}$-larvae to the eel.

Paratenic hosts accumulate the invasive larvae and contribute to their transfer to the definitive host but are not essential for the completion of the life-cycle (Ryzhikov 1964). Probably not all fish species nor size classes which carry larvae actually function as paratenic host. Some of the species were rather occasionally infected and showed no accumulation of the larvae: rudd, roach, ide, tench and even bleak (up to 4 larvae). Although these species are occasionally infected they will not play an important part in the life cycle and must be considered as accidental hosts. Viability and infectivity of the larvae in the different fish species is important, but we could not determine the longevity of the $\mathrm{L}_{3}$-larvae. In perch the $\mathrm{L}_{3}$-larvae continued to develop to the $\mathrm{L}_{4}$ - and pre-adult stage, which will normally not be infective to eel anymore. Therefore, perch cannot be considered as a good paratenic host, but neither as a good definitive host because no progeny was ever observed. As a rule paratenic hosts of helminths serve as food for their definitive hosts. Although infection was not restricted to small size classes, e.g. large perch or pike-perch, these larger fish do not serve as food for the eel.

Still there is a wide range of possible paratenic hosts with high infection rates which may help to explain the very rapid and wide distribution of Anguillicola in Europe.

Acknowledgements. The authors are most grateful to P. Van Damme and C. Kennedy for comments on the manuscript. The first author was supported by the National Science Foundation of Belgium (NFWO).

\section{LITERATURE CITED}

Anderson, R. M. (1978). The regulation of host population growth by parasitic species. Parasitology 76: 119-157

Anderson, R. M. (1987). The role of mathematical models in helminth population biology. Int. J. Parasit. 17: 519-529

Belpaire, C., De Charleroy, D., Grisez, L., Ollevier, F. (1989). Spreading mechanisms of the swimbladder parasite Anguillicola crassus in the European eel Anguilla anguilla and its distribution in Belgium and Europe. European Inland Fishery Advisory Commission (FAO), Working Party on Eel, Porto, Portugal, May 29-June 3

Canestri-Trotti, G. (1987). Occurrence of the nematode Anguillicola crassa Kuwahara, Niimi \& Itagaki, 1974 in eels from the Po delta, Italy. Bull. Eur. Ass. Fish Pathol. $7(5): 109-111$

De Charleroy, D., Grisez, L., Thomas, K., Belpaire, C., Ollevier, F. (1990). The life cycle of Anguillicola crassus. Dis. aquat. Org. 8: 77-84

Dekker, W., van Willigen, J. (1987). Short note on the distribution and abundance of Anguillicola in the Netherlands. European Inland Fishery Advisory Commission (FAO), Working Party on Eel, Bristol, U.K., 13-16 April

De Nie, H. W. (1988). Food, feeding and growth of the eel (Anguilla anguilla L.) in a Dutch eutrophic lake. Ph. D. dissertation, Agricultural University Wageningen

Dupont, F., Petters, A. (1988). Anguillicolà, un épizootie plurispécifique en Europe. Apparition d'Anguillicola crassa (Nematoda, Anguillicolidae) chez l'anguille européenne (Anguilla anguilla) en Camargue, Sud de la France. Bull. Fr. Pech. Pisci. 308: 38-41 (in French)

Haenen, O. L. M., van Banning, P. (1990). Detection of larvae of Anguillicola crassus (an eel swimbladder nematode) in freshwater fish species. Aquaculture 87: 103-109

Haenen, O. L. M., van Banning, P. (1991). Experimental transmission of Anguillicola crassus (Nematoda, Dracunculoidea) larvae from infected prey fish to the eel, Anguilla anguilla. Aquaculture 92: 115-119

Hellström, A., Ljungberg, O., Bornstein, S. (1988). Anguillicola, en ny ălparasit i Sverige. Svensk Veterinärtidning. 40(4): 211-213 (in Swedish)

Hirose, H., Sekino, T., Egusa, S. (1976). Notes on the egg deposition, larval migration and intermediate host of the nematode Anguillicola crassa parasite in the swimbladder of eels. Fish Pathol. 11(1): 27-31 (in Japanese with English abstract) 
Höglund, J., Thomas, K. (1992). The black goby Gobius niger serve as paratenic host for the parasitic nematode Anguillicola crassus in a thermal effluent of the Baltic. Dis. aquat. Org. 13: 175-180

Huang, L. F. (1981). Studies on the life history of Anguillicola globiceps. Dongwuxue zazhi (Zoological magazine) 1: 24-25 (Abstract in Helminth. Abs. 1982)

Keast, A., Webb, D. (1966). Mouth and body form relative to feeding ecology in the fish fauna of a small lake, Lake Opinicon, Ontario. J. Fish. Res. Bd Can. 23(12): 1845-1874

Kennedy, C. R., Fitch, D. J. (1990). Colonization, larval survi$\mathrm{val}$ and epidemiology of the nematode Anguillicola crassus, parasitic in the eel, Anguilla anguilla, in Britain. J. Fish Biol. 36: 117-131

Kim, Y.-G., Kim, E.-B., Kim, J.-Y., Chun, S.-K. (1989). Studies on a nematode, Anguillicola crassa parasitic in the air bladder of the eel. J. Fish Pathol. 2(1): 1-18 (in Korean with English abstract)

Kuwahara, A., Nimi, A., Itagaki, H. (1974). Studies on a nematode parasitic in the air bladder of the eel. I. Description of Anguillicola crassa n. sp. (Philometridae, Anguillicolidae). Jap. J. Parasitol. 23(5): 275-279

Koie, M. (1988). Parasites in eels, Anguilla anguilla (L.), from eutrophic Lake Esrum (Denmark). Acta Parasitol. Pol. 33: $89-100$

Lazzaro, X. (1987). A review of planktivorous fishes: their evolution, feeding behaviour, selectivities, and impacts. Hydrobiologia 146: 97-167

Margolis, L., Esch, G. W., Holmes, J. C., Kuris, A. M., Schad, G. A. (1982). The use of ecological terms in parasitology (report of an ad hoc committee of the American Society of Parasitologists). J. Parasitol. 68: 131-133

Peters, G., Hartmann, F. (1986). Anguillicola, a parasitic

Responsible Subject Editor: W. Körting, Hannover, Germany nematode of the swimbladder spreading among eel populations in Europe. Dis. aquat. Org. 1. 229-230

Rohde, K. (1980). Host specificity indices of parasites and their application. Experientia 36: 1369-1371

Ryzhikov, K. M. (1964). Reservoir parasitism in helminths Proc. 1st int. Congr. Parasitol. 1 23-25

SAS Institute Inc. (1989). SAS/STAT User's Guide, Version 6. 4 th edn, Vol. 2. SAS Institute Inc., Cary, North Carolina

Sinha, V R. P., Jones, J. W. (1967). On the food of the freshwater eels and their feeding relationship with the salmonids. J. Zool. 153: 119-137

Smith, J. D. (1984). Development of Raphidascaris acus (Nematoda, Anisakidae) in paratenic, intermediate, and definitive hosts. Can. J. Zool. 62: 1378-1386

Székely, C., Láng, M., Csaba, G. (1991). First occurrence of Anguillicola crassus in Hungary. Bull. Eur Ass. Fish Pathol. 11(4): 162-163

Taraschewski, H., Moravec, F., Lamah, T., Anders, K. (1987). Distribution and rnorphology of two helminths recently introduced into European eel populations: Anguillicola crassus (Nematoda, Dracunculoidea) and Paratenuisentis ambiguus (Acanthocephala, Tenuisentidae). Dis. aquat. Org. 3: $167-176$

Tesch, F.-W. (1977). The eel: biology and management of anguillid eels. Chapman \& Hall, London

Verreycken, H., Belpaire, C., Ollevier, F. (1990). Studie naar de impact van het inzuigen van koelwater door de Electrabelcentrale te Langerlo op de vispopulaties van het Albertkanaal en de Kolenhaven. K. V Leuven report contracted by Electrabel, Genk, Belgium (In Dutch)

Wang, P., Zhao, Y (1980). Observations on the life history of Anguillicola globiceps (Nematoda: Anguillicolidae). Acta Zool. Sin. 26(3): 243-249

Manuscript first received: March 2, 1992

Revised version accepted: May 12, 1992 